\title{
EL DESIERTO CONMOVIDO
}

\author{
Héctor González, Cortez ${ }^{1}$
}

El 17 de febrero pasado nos enteramos del sorpresivo fallecimiento de nuestro querido colega Luis Eduardo Briones Morales, con quien seguíamos fuertemente unidos, tanto académica como afectivamente, a pesar de que se había acogido a retiro el año 2010. La pena y aflicción que sentimos todos los miembros del Departamento de Antropología es enorme. Solo su familia, su esposa Any, sus hijos Viviana y Esteban, sus nietos, sus hermanas (su madre Elba, que le sobrevive más que centenaria, todavía no ha sido enterada), y también el desierto que tanto amó, pueden estar más conmovidos que nosotros con el dolor de su partida.

Cuando Patricio Advis (2008), su amigo, usó la expresión "El Desierto Conmovido" para titular uno de sus libros, podíamos dudar que el paso de Diego Almagro y sus huestes, al que está dedicada esa obra, pudiese en realidad conmover tan inmenso paisaje. Hoy sí estamos seguros. Su habitante más querido, el que conocía mejor la esencia del arte que dejaron los antiguos, el mejor caminante de sus rutas ancestrales nos ha dejado. Y nos duele tanto que podemos hacer nuestros los versos de Wystan H. Auden (1959 [1936]): "Ya no queremos a las estrellas, apáguenlas todas, empaquen la luna y desmantelen el sol...", paren todos los relojes del desierto, que el más sabio protector de las imágenes ancestrales grabadas en sus piedras y cerros ha partido, quizás para vivir eternamente bajo su abrigo.

El profesor Briones se formó en la Facultad de Bellas Artes de la Universidad de Chile en Santiago, donde obtuvo su título de Profesor de Estado en Artes Plásticas. Como siempre señala Lautaro Núñez Atencio, su primo, su hermano, nuestro querido Lucho, nuestro Lalo en el círculo íntimo, fue un hijo de la educación pública, un niño del oasis de Pica que hizo sus estudios primarios en la escuela de su pueblo, que se trasladó a la ciudad de Iquique a cursar su enseñanza media y cursó sus estudios superiores en la capital, en la Universidad estatal más importante del país, para transformarse en un profesional, el primer profesional de su familia.
Después de titularse y trabajar un tiempo como profesor en un Liceo de San Miguel, se incorporó en 1974 a la sede Arica de la Universidad de Chile, al ganar un concurso de oposición de antecedentes abierto por el Departamento de Artes, que se preparaba para abrir en 1975 la carrera de Pedagogía en Artes Plásticas. Se hizo cargo de la catedra de Historia del Arte Iberoamericano. Como él mismo decía: "Yo me propuse enseñar el arte que conocimos en la arqueología, comencé a enseñar el arte iberoamericano prehispánico, desde México a Tierra del Fuego".

Esta disposición se explica por el ambiente intelectual americanista que rodeó su formación universitaria en el Arte, pero también por la impresión imperecedera que en su niñez y adolescencia le provocó el pasado tarapaqueño, cuyas huellas buscaba con su primo Lautaro y otros amigos en sus recorridos por la pampa y la costa. El arte prehispánico impreso en las rocas y cerros por los antiguos habitantes del desierto formó tempranamente parte de su propia experiencia de vida. Por ello, no es extraño que se integrara a los primeros equipos de profesionales locales ocupados en la arqueología tarapaqueña, y que su memoria de titulación fuese "Petroglifos del Distrito Arqueológico de Tarapacá: Contribución a la Arqueología del Norte de Chile" (Briones 1967).

Su interés por vincular el arte con la arqueología queda de manifiesto también cuando un año después de llegar a Arica, publica en la Revista de la Universidad de Chile de la sede local un trabajo sobre los grandes geoglifos del Valle de Lluta, en conjunto con Percy Dauelsberg, Sergio Chacón y Luis Álvarez, próceres de la arqueología ariqueña (Dauelsberg et al. 1975). En estos años empieza también su incansable labor en restauración y conservación del arte rupestre, especialmente de la puesta en valor de los geoglifos, que se inició en los valles de Lluta y Azapa, y se extendió posteriormente por todo el Norte Grande de nuestro país. Su preocupación por la puesta en valor del arte prehispánico lo llevó a viajar al Cusco en 1979 para capacitarse en su restauración.

1 Departamento de Antropología, Universidad de Tarapacá, Arica, Chile. 
Luis se incorpora a la Universidad de Tarapacá en 1981, que es creada ese año con la fusión de las sedes que mantenían en Arica la Universidad de Chile (transformada por un corto periodo en el Instituto Profesional de Arica) y la Universidad del Norte. En ese momento se integra al entonces Instituto de Antropología de la Universidad, nuestro actual Departamento (donde permaneció hasta retirarse a los 70 años). Esto significó también el cambio de su domicilio académico, pasando del Campus Velásquez al Campus Azapa, en las dependencias del Museo San Miguel de Azapa. Aquí continuó con su interés investigativo por el arte rupestre y su conservación. A comienzos de los años ochenta encabeza un convenio suscrito entre la Universidad de Tarapacá y el Servicio Nacional de Turismo (SERNATUR) regional, que permite la restauración de otros sectores con geoglifos, como los de Chiza, Tiliviche, Ex Aura, Cerro Unita y también los de Cerros Pintados, cuyas imágenes conocía desde niño y lo despedían cuando tomaba el antiguo tren en la Estación Pintados para viajar a Santiago a estudiar Arte.

Aparte de continuar con sus investigaciones sobre el arte rupestre, y su permanente preocupación por ponerlo en valor, en esa misma década agrega el que será su otro gran campo de interés, el arte religioso colonial indígena. En 1983 lo anunciaba, al publicar el libro "Pintura Religiosa en Tarapacá: Fe y Color en el Desierto" (Briones y Vilaseca 1983). Luis lideró el equipo de nuestro Departamento que participó en un proyecto binacional dedicado al catastro, evaluación y estudio del arte mural andino, realizado por la Universidad de Tarapacá y el Instituto Boliviano de Cultura, que fue financiado por la Organización de Estados Americanos en los años 1986-1987; que continuó con otro de carácter trinacional, incluyendo también a Perú, financiado por el mismo organismo multilateral, dedicado al arte y patrimonio de la Ruta de la Plata.

Luis Briones combinó de manera notable la preocupación de generar conocimiento sobre nuestro patrimonio a través del estudio científico y la necesidad de ponerlo en valor y, sobre todo, defenderlo. Entendió tempranamente, cuando esta preocupación no existía, al menos no en nuestro país, la importancia del patrimonio como memoria imperecedera para las generaciones del futuro; y también de su relevancia para el desarrollo del turismo de intereses especiales, un sostén que puede tener una importancia económica más permanente que las actividades extractivas de nuestros recursos naturales, que alumbran solo jalones de la historia del desierto para luego apagarse. Si en un momento pudo recordarnos la imaginaria figura de un Quijote luchando contra molinos de viento, con los años la historia terminó ubicándolo en el lugar real que le correspondía. El año 2012 fue galardonado con el Premio Nacional de Conservación del Patrimonio Cultural de Chile.

También fue declarado Hijo Ilustre de Arica e Hijo Ilustre de Pica. Este último premio era el que más apreciaba. El niño del oasis que se marchó para lograr ser el primer profesional de su familia había retornado a vivir a su tierra al retirarse de las aulas, y el prestigio que había alcanzado con su trabajo era reconocido por su propio pueblo. Incansable, continuó con su actividad. Sus colegas de la Universidad lo sabemos, pero también los que encontró en el Museo de Pica, donde tuvo su última oficina. Su vitalidad no correspondía a la de su edad. Nada ni nadie parecía podía parar su eterna inquietud por comprender el arte del desierto. Solo su propio corazón.

La revista Chungara está de duelo. En su memoria dedicaremos lo que resta del volumen correspondiente a este año a nuestro colega. En este número, aparte de esta presentación, incluimos dos aportes que retratan su vida académica desde su ambiente familiar. El de su primo Lautaro Núñez Atencio reseña su vida profesional y académica y el de su hija Viviana Briones Valentín nos la presenta desde un lado más íntimo. En los próximos números incorporaremos dos trabajos referidos a su contribución a los principales ámbitos de su preocupación académica: el arte rupestre y el arte colonial indígena. Es nuestra manera de hacer que "permanezca a nuestro lado para no perderle ahora", como escribió Alfred Tennyson en su poema In Memoriam (2000 [1850]). Pero sabemos que tendremos que conformarnos, y como lo harían los antiguos habitantes del barrio El Morro de su liceana adolescencia iquiqueña, lo despedimos con un "¡Avísale Lalo, desde tu eternidad!".

\section{Referencias Citadas}

Advis, P. 2008. El Desierto Conmovido. Paso de la Hueste de Almagro por el Norte de Chile. Dirección de Extensión Académica y Cultural, Universidad Arturo Prat, Iquique.
Auden, W.H. 1959 [1936]. Stop all the clocks, cut off the telephone. En Collected Shorter Poems 1930-1944, W.H. Auden, p. 58. Faber and Faber Limited, Londres. 
Briones, L. 1967. Petroglifos del Distrito Arqueológico de Tarapacá: Contribución a la Arqueología del Norte de Chile. Memoria para optar al título de Profesor de Artes Plásticas, Departamento de Arte, Universidad de Chile, Santiago.

Briones, L. y P. Vilaseca 1983. Pintura Religiosa en Tarapacá: Fe y Color en el Desierto. Editora e Impresora Cabo de Hornos, Santiago.
Dauelsberg, P., L. Briones, S. Chacón, E. Vásquez y L. Álvarez 1975. Los grandes geoglifos del valle del Lluta. Revista Universidad de Chile Sede Arica 3:13-16.

Tennyson, A. 2000 [1850]. In Memoriam A.H.H. En Alfred Tennyson, editado por A. Roberts, pp. 203-292. Oxford University Press, Nueva York. 
